\title{
Kinetics of Formation and Crystal Structure Determination of $\mathrm{Sr}_{4} \mathrm{Al}_{6} \mathrm{O}_{12} \mathrm{SO}_{4}$
}

\author{
José Amparo Rodríguez ${ }^{a}$, Estrella Guadalupe Ríos Rodríguez $z^{a}$ Enrique Rocha Rangel ${ }^{\star *}$,José
}

Manuel Almanza Robles ${ }^{b}$,Jesús Torres ${ }^{b}$, Elizabeth Refugio García ${ }^{c}$

${ }^{a}$ Parque Cientifico y Tecnológico de Tamaulipas, Universidad Politécnica de Victoria, Avenida Nuevas Tecnologías 5902, Ciudad Victoria, Tamaulipas, 87138, México

${ }^{b}$ Centro de Investigación y de Estudios Avanzados Unidad Saltillo, Industria Metalúrgica 1062, Parque industrial Saltillo-Ramos Arizpe, Ramos Arizpe, Coahuila, 25900, México

${ }^{c}$ Departamento de Materiales, Universidad Autónoma Metropolitana, Avenida San Pablo 180, Colonia Reynosa-Tamaulipas, D.F., 02200, México

Received: September 03, 2016; Revised: November 28, 2016; Accepted: December 27, 2016

The sulphoaluminate of strontium, $\mathrm{Sr}_{4} \mathrm{Al}_{6} \mathrm{O}_{12} \mathrm{SO}_{4}$, was synthesized by solid state reaction from mixture of $\mathrm{SrCO}_{3}, \mathrm{Al}_{2} \mathrm{O}_{3}$ and $\mathrm{SrSO}_{4}$ (3:3:1 molar ratio) as pellets. The kinetics of formation has been studied in the range of temperature between $850^{\circ} \mathrm{C}$ and $1100^{\circ} \mathrm{C}$ using quantitative $\mathrm{X}$-ray powder diffraction data (XRD) analysis. Likewise, at room temperature, the crystal structure was determined from conventional X-ray powder diffraction data using direct methods and it was refined by the Rietveld method. The kinetics mechanisms that showed the best fit, were identified as geometrical contraction at grain boundary $\left(R_{1.1}\right)$ and nucleation and growing by energy law $\left(P_{1.1}\right)$. The activation energy values obtained were $145.47 \mathrm{KJmol}^{-1}\left(R_{l .1}\right)$ and $151.35 \mathrm{KJmol}^{-1}\left(P_{l .1}\right)$, respectively. The resulting crystal structure was orthorhombic type (a: $13.32802 \AA$, b: $13.34430 \AA$ and c: $9.38704 \AA$ ). The observed adjustment parameters were $\mathrm{R}_{\mathrm{B}}: 0.0985, \mathrm{R}_{\mathrm{wp}}: 0.137, \mathrm{R}_{\mathrm{p}}: 0.0925$ and $\mathrm{Chi}^{2}: 1.94$.

Keywords: Solid state reaction, Kinetic study, Crystal structure, Rietveld method

\section{Introduction}

Reactions between solids are diverse, determinants being i) the thermodynamic conditions, ii) structural conditions and iii) reaction mechanisms governing the process. The Knowledge of the kinetic mechanisms that characterize a solid state reaction is essential for the control of a process, critical issue in the development of new products ${ }^{1}$. However, there are few mathematical descriptions which provide suitable bases for prediction and interpretation of such reactions. On the other hand, knowledge of the crystal structure of any material is a fundamental requirement to understand and control the properties ${ }^{2}$. In recent decades they have seen a considerable increase in the development of the structure determination from powder diffraction data ${ }^{3-5}$. An example is the Rietveld method, computational program whose objective is the refining of crystal structures using the technique of least squares by adjusting the patterns (experimental and calculated) ${ }^{2}$. Due to the above and knowing that the information about the compounds formed within the system $\mathrm{SrO}-\mathrm{Al}_{2} \mathrm{O}_{3}-\mathrm{SrSO}_{4}$ is low (only synthesis at high temperature, some physical and chemical properties of $\mathrm{Sr}_{4} \mathrm{Al}_{6} \mathrm{O}_{12} \mathrm{SO}_{4}$ were reported $)^{6-10}$ as an integral part of the synthesis and characterization of strontium sulfoaluminate, $\mathrm{Sr}_{4} \mathrm{Al}_{6} \mathrm{O}_{12} \mathrm{SO}_{4}$, this paper presents i) the kinetic study of the formation from quantitative data best fit against kinetic models by solid state reaction and ii)

*e-mail: erochar@upv.edu.mx the crystal structure at room temperature through the refining of X-ray diffraction patterns using the Rietveld method.

\section{Experimental Procedure}

The research was conducted in three stages; in the first stage the preparation and characterization of the samples are presented, in the second stage a study was performed to establish the kinetic of formation of $\mathrm{Sr}_{4} \mathrm{Al}_{6} \mathrm{O}_{12} \mathrm{SO}_{4}$ in the $\mathrm{SrO}-\mathrm{Al}_{2} \mathrm{O}_{3}-\mathrm{SrSO}_{4}$ system and the third stage the crystal structure of the same strontium compound was determined.

\subsection{Preparation and characterization of samples}

Stoichiometric mixture of $\mathrm{Al}_{2} \mathrm{O}_{3}, \mathrm{SrCO}_{3}$ and $\mathrm{SrSO}_{4}(3: 3: 1$ ratio molar) were accurately weighed and homogenized for 4 hours in plastic jar with acetone and alumina balls on spinning rolls. The mixtures was dried in a furnace at $100^{\circ} \mathrm{C}$ for 24 hours. After drying the mixture was ground in a mortar to disintegrate agglomerates. Disk pellets $(20 \mathrm{~mm}$ of diameter and $3 \mathrm{~mm}$ thick), were made for each mixture by uniaxial pressing using at steel die. Press loading of $100 \mathrm{MPa}$ was used for all experiments. The samples were introduced into high alumina crucibles and were heat treated from 800 to $1400^{\circ} \mathrm{C}$ with isotherms of $4,6,8$ and 10 hours, with a heating-cooling rate of $10^{\circ} \mathrm{Cmin}^{-1}$ and without the use of a special gas to generate an enveloping atmosphere. 
To avoid possible chemical reactions between the samples and the crucibles, the dicks pellets were placed inside the crucible on a powder layer of the same stoichiometric mixture (previously described) and then covered with the same stoichiometric powder mixture before placing the alumina cap on the crucible. Subsequently, samples were analyzed by X-ray powder diffraction (XRD) and scanning electron microscopy (SEM). The samples analyzed by SEM (Philips XL30/ESEM) were cross sectioned and grinded using $\mathrm{SiC}$ grinding media from 80 to 2400 grit size. Then the samples were polished using a $1 \mu \mathrm{m}$ diamond paste and treated to remove impurities in ultrasonic bath. Morphology of the phases present in each reaction step, were observed and semi-quantitative analysis (EDS) was performed. The samples analyzed by XRD, previously ground in a mortar until a fine grain size was obtained (30gr). In this way, randomly orientated samples were prepared to avoid preferred orientation. The X-ray diffractometer used (Philips TW-3040) with a monochromatic $\mathrm{Cu}-\mathrm{K} \alpha$ radiation operating voltage of $50 \mathrm{KV}$ and a current of $30 \mathrm{~mA}$. At room temperature, a scanning speed of $0.10^{\circ} 2 \theta \mathrm{min}^{-1}$ and a step size of $0.02^{\circ}$ were used to examine the samples in the range $10-80^{\circ} 2 \theta$. The crystalline phases were identified by means of the PAN-ICSD database version 2013-1.

\subsection{Kinetic study}

Kinetic models governing the formation of $\mathrm{Sr}_{4} \mathrm{Al}_{6} \mathrm{O}_{12} \mathrm{SO}_{4}$ by solid state reaction in the $\mathrm{SrO}-\mathrm{Al}_{2} \mathrm{O}_{3}-\mathrm{SrSO}_{4}$ system were determined. The main objectives of kinetic study were i) identifying the kinetic model(s) that describe the formation of products and ii) determining the influence of temperature on the reaction rate. In both cases it was necessary to know the full extent of the reaction, that is, progressive changes from reactants to products in a given time. Such changes, known as reacted fraction ${ }^{1}$, were calculated by using Equation 1:

$$
\alpha=\frac{m_{0}-m_{t}}{m_{0}-m_{f}}
$$

Were $m_{o}$ is the initial amount of product, $m_{t}$ is the amount of product at time $t$ and $m_{f}$ is the final amount of product. The amounts of all the reaction products (strontium compounds) formed during the reactions steps were determined by quantitative $\mathrm{X}$-ray powder diffraction data analysis, using the Sietronics Traces 3.0 software and were plotted as reacted fraction versus time. The basic equation that defines the reaction rate is 1 :

$$
\frac{\partial \alpha}{\partial t}=A \exp \left(\frac{-E_{a}}{R T}\right) f(\alpha)
$$

Where $\alpha$ represents the reacted fraction $(0<\alpha<1)$ in the solid reactant during the course of the reaction, $A$ is the Arrhenius pre-exponential factor, $T$ is the temperature of the reaction, $f(\alpha)$ is the kinetic function and depends on the reaction mechanism, $E_{a}$ is the activation energy for the reaction and $R$ is the gas constant. If the reaction rate is constant, applying the logarithm and rearranging the equation:

$$
\ln f(\alpha)=\frac{E_{a}}{R T}+\ln \left(\frac{C}{A}\right)
$$

Considering that the term $\ln (\mathrm{C} / \mathrm{A})$ is constant, by plotting $f(\alpha)$ against $1 / T$ for various functions, it is possible to determine the kinetic model(s) describing the mechanism through which the reaction occurs, using the method of adjustment functions ${ }^{1}$. Namely, the experimental curves were compared with ideal curves, these second obtained from the introduction of fraction reacted values in different kinetics models for solid state reaction reported in the literature, being determined kinetic model(s) have greater adjustment functions ${ }^{11}$. Kinetic phenomena were observed in the samples analyzed by SEM in each reaction step.

\subsection{Crystalline structure determination}

The crystal structure of $\mathrm{Sr}_{4} \mathrm{Al}_{6} \mathrm{O}_{12} \mathrm{SO}_{4}$ was determined. The structure and microstructure features of the prepared samples were obtained from $\mathrm{X}$-ray powders diffraction data of the same heat treated at $1400^{\circ} \mathrm{C}$ with 4 hours isotherm. The measured angular range, the step size and counting times were selected to ensure enough resolution (the step size should be at least, 1/10 of the fwhms) and statistics. The structural refinements were carried out by the Rietveld method using the Fullprof program ${ }^{2}$; in some cases, a severe microstructural contribution to the profile must be considered. The background intensities were fitted to a polynomial function with ten adjustable parameters. A phenomenological approach was applied using a capability of the program which allows some of the peaks to be described by their own breadths and shapes, as well as small displacements from their positions calculated from the average unit cell. Prior to the structure refinements, a pattern matching without structural model was performed. This procedure allows obtaining suitable profile parameters, including the breadths, shapes and displacements of those reflections with relevant microstructural contributions. An overall isotropic thermal factor (ITF) was used for all the atoms in the structure. The fitting process was finished when convergence is reached.

\section{Results and Discussion}

\subsection{Kinetic study}

The kinetic of formation of strontium sulphoaluminate, $\mathrm{Sr}_{4} \mathrm{Al}_{6} \mathrm{O}_{12} \mathrm{SO}_{4}$, within the system $\mathrm{SrO}-\mathrm{Al}_{2} \mathrm{O}_{3}-\mathrm{SrSO}_{4}$ was studied. Figure 1 shows the quantitative $\mathrm{X}$-ray powder diffraction data analysis for all samples were heat treated 

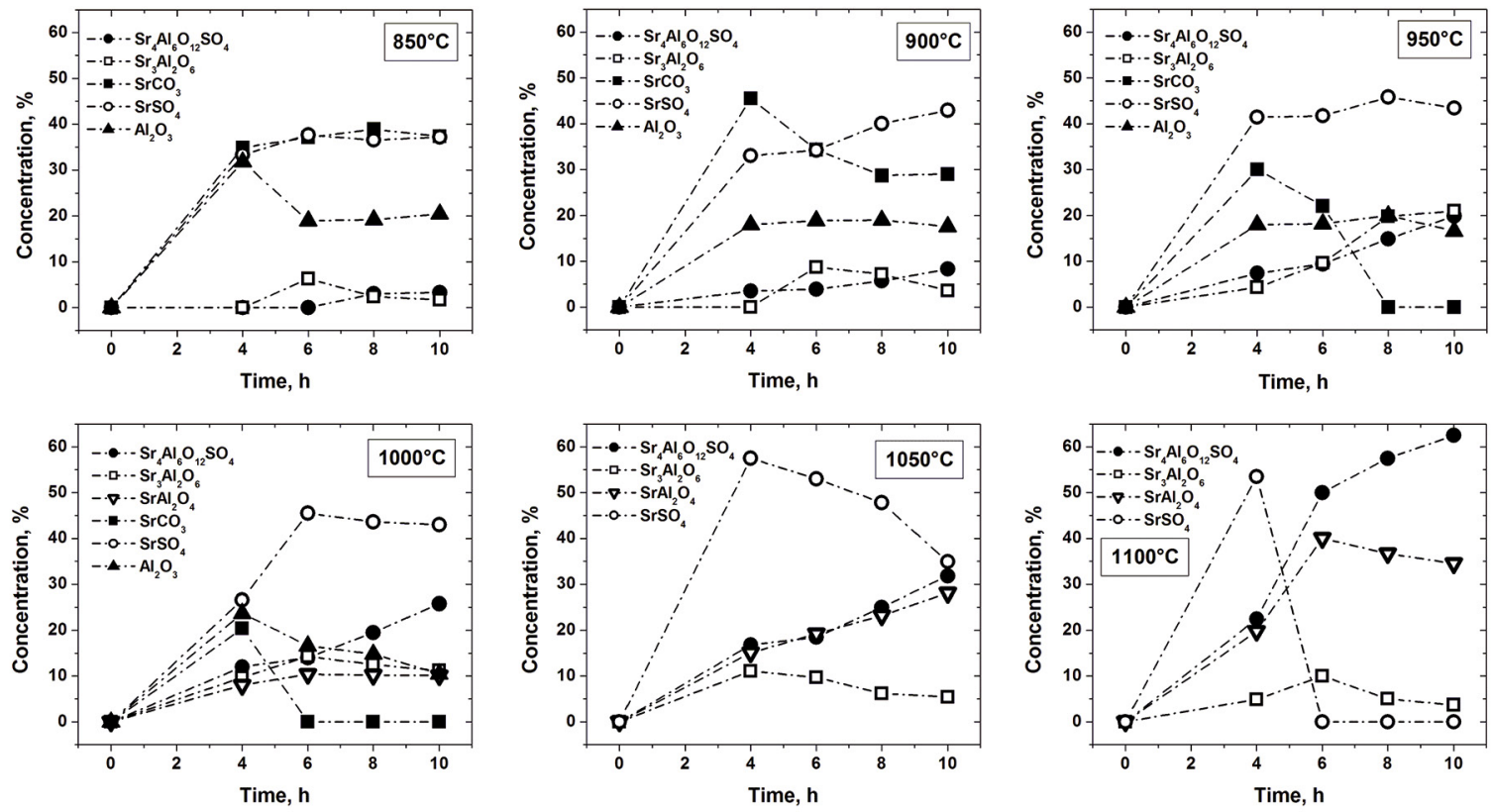

Figure 1: Formation of strontium compounds and starting reagents, quantified by X-ray powder diffraction data for samples of the $3 \mathrm{Al}_{2} \mathrm{O}_{3}: 3 \mathrm{SrCO}_{3}: \mathrm{SrSO}_{4}$ mixture, heat treated at several temperatures and isotherms.

in the temperature range from 850 to $1100^{\circ} \mathrm{C}$ and different isotherms.

As shown in Figure 1, as strontium compounds are produced the three starting reagents, $\mathrm{SrCO}_{3}, \mathrm{SrSO}_{4}$ and $\mathrm{Al}_{2} \mathrm{O}_{3}$, remaining quantity decreases, strontium sulfate only remains to the final stage of the reaction. With the process of decomposition of the strontium carbonate in oxide (starts at low temperatures), results in the formation of strontium compounds. At all six temperatures studied, $\mathrm{Sr}_{4} \mathrm{Al}_{6} \mathrm{O}_{12} \mathrm{SO}_{4}$ was formed (result of the reaction between $\mathrm{SrO}, \mathrm{SrSO}_{4}$ and $\mathrm{Al}_{2} \mathrm{O}_{3}$ ) and its amount increases gradually with increasing temperature and time. Likewise, the presence of two strontium aluminates, $\mathrm{Sr}_{3} \mathrm{Al}_{2} \mathrm{O}_{6}$ and $\mathrm{SrAl}_{2} \mathrm{O}_{4}$, as intermediate phases were formed (reaction between $\mathrm{SrO}$ and $\mathrm{Al}_{2} \mathrm{O}_{3}$ ) initially and persisted until the reaction to form $\mathrm{Sr}_{4} \mathrm{Al}_{6} \mathrm{O}_{12} \mathrm{SO}_{4}$ was nearly complete. $\mathrm{Sr}_{3} \mathrm{Al}_{2} \mathrm{O}_{6}$ was formed at $850^{\circ} \mathrm{C}$, reached a maximum at $950^{\circ} \mathrm{C}$ with 10 hours isotherms and subsequently decreased. Meanwhile, $\mathrm{SrAl}_{2} \mathrm{O}_{4}$ was formed at $1000^{\circ} \mathrm{C}$ and its amount increases gradually with increasing temperature and time, reached a maximum at $1100^{\circ} \mathrm{C}$ with 6 hours isotherms. In the case of this type of aluminate $\left(\mathrm{SrAl}_{2} \mathrm{O}_{4}\right)$, its formation has been previously explained: at temperatures lower than the transformation temperature of $\mathrm{SrCO}_{3}$ from orthorhombic to hexagonal $\left(<920^{\circ} \mathrm{C}\right)$, the formation of strontium compounds is attributed to the interfacial reaction between $\mathrm{SrCO}_{3}$ and alumina. Conversely, at temperatures higher that $920^{\circ} \mathrm{C}$, the solid-state reaction is dominated by the diffusion of $\mathrm{Al}^{+3}$ ions into the $\mathrm{SrCO}_{3}$ lattice ${ }^{12-13}$. At $1100^{\circ} \mathrm{C}$ these strontium aluminates, $\mathrm{Sr}_{3} \mathrm{Al}_{2} \mathrm{O}_{6}$ and $\mathrm{SrAl}_{2} \mathrm{O}_{4}$, reacted with $\mathrm{SrSO}_{4}$ to form $\mathrm{Sr}_{4} \mathrm{Al}_{6} \mathrm{O}_{12} \mathrm{SO}_{4}$. To supplement the results, at $1150^{\circ} \mathrm{C}$ with 4 hours isotherm, the main identified phase was $\mathrm{Sr}_{4} \mathrm{Al}_{6} \mathrm{O}_{12} \mathrm{SO}_{4}$.
This indicated that the formation of this compound is complete at $1150^{\circ} \mathrm{C}$. The amount of $\mathrm{Sr}_{4} \mathrm{Al}_{6} \mathrm{O}_{12} \mathrm{SO}_{4}$ formed at several temperatures is plotted as fraction reacted, $\alpha$, as a function of time in Figure 2.

This amount always increased with increase in temperature and the reaction approached completion at the highest temperatures. Shows the two models that had the best fit compared with the results. These two models corresponded to $R_{1.1}$ (geometrical contraction at grain boundary, $1-(1-\alpha)^{1 / n}$ and $P_{1.1}$ (nucleation and growth by the energy law, $\left.\alpha^{1 / n}\right)$. The value of " $n$ " in both models was varied from 1 to 3 and the best fit was found to be 1.1 for each one. The kinetics study always gives an approximation of the phenomenon that is occurring; in this case both models can explain the kinetics formation of strontium compound $\mathrm{Sr}_{4} \mathrm{Al}_{6} \mathrm{O}_{12} \mathrm{SO}_{4}$. For the $R_{1.1}$ model it can be observed that the values of fraction formed did not fit exactly with the model for the curve at $1100^{\circ} \mathrm{C}$. On the other hand for $1100^{\circ} \mathrm{C}$ the model $P_{1.1}$, fits accurately with experimental data. An analysis of Figure 1, can help to explain the influence of both model in the kinetics of $\mathrm{Sr}_{4} \mathrm{Al}_{6} \mathrm{O}_{12} \mathrm{SO}_{4}$ formation. At low temperatures 800 to $950^{\circ} \mathrm{C}$, the amount of $\mathrm{SrCO}_{3}$ decreased considerably. This decreased in the amount of strontium carbonate indicates a rapid decomposition of $\mathrm{SrCO}_{3}$ in the sample volume, to form $\mathrm{SrO}$ available to react with $\mathrm{Al}_{2} \mathrm{O}_{3}$ and $\mathrm{SrSO}_{4}$ to form the strontium sulphoaluminate $\mathrm{Sr}_{4} \mathrm{Al}_{6} \mathrm{O}_{12} \mathrm{SO}_{4}$. This process presents a fast and dense initial nucleation at constant speed through all or some crystalline phases, due to the formation of interface reaction zones (low values fraction reacted), with diffusive effects and geometrical contraction. At high temperatures (high values of fraction reacted) reaction zones 

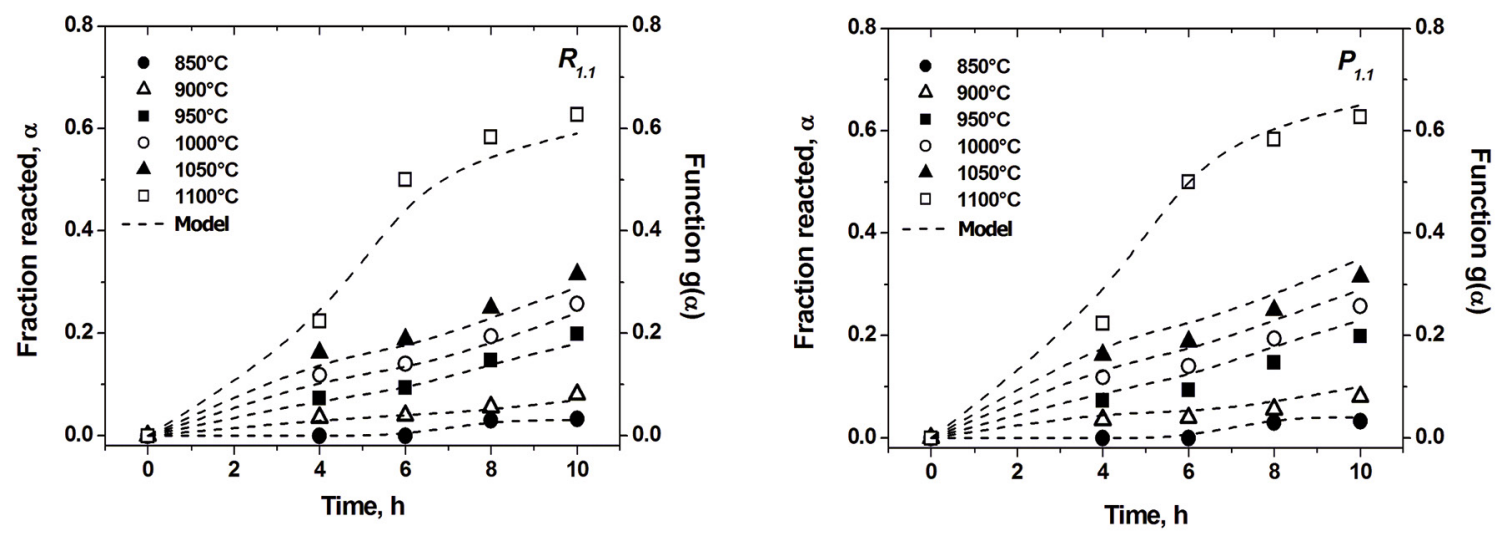

Figure 2: Kinetics models fit for the fraction formed of $\mathrm{Sr}_{4} \mathrm{Al}_{6} \mathrm{O}_{12} \mathrm{SO}_{4}$ as function of temperature and time.

(active interface) is increased, producing a greater number of nuclei in conjunction with the growth of these to form the total product volumer. Figure 3 shows micrographs of typical samples of $3 \mathrm{Al}_{2} \mathrm{O}_{3}: 3 \mathrm{SrCO}_{3}: \mathrm{SrSO}_{4}$ mixture, heat treated from 800 to $1150^{\circ} \mathrm{C}$ with $4 \mathrm{~h}$ isotherm, to observe the kinetic mechanisms governing the formation of $\mathrm{Sr}_{4} \mathrm{Al}_{6} \mathrm{O}_{12} \mathrm{SO}_{4}$.
In Figure 3A nuclei of $\mathrm{SrO}$ (1) were identified into the sectioned particles of $\mathrm{SrCO}_{3}(2)$, according to EDS analysis. In Figure $3 \mathrm{~B}$ the amount of strontium oxide (dark zone) were increased and even, from blowing to form nuclei within the same area of $\mathrm{SrO}$. This process of decomposition of $\mathrm{SrCO}_{3}$ to $\mathrm{SrO}$ is carried out throughout
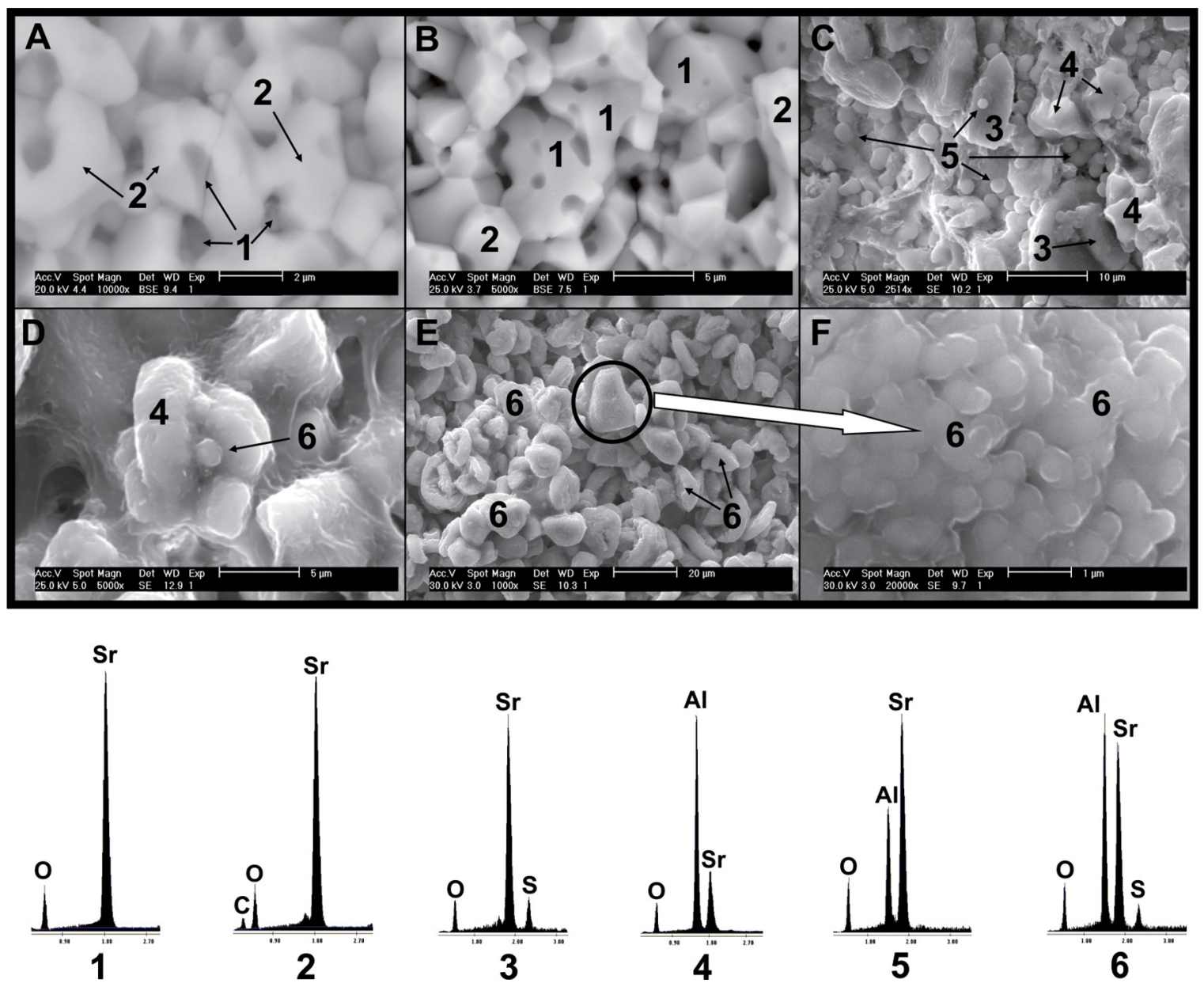

Figure 3: Micrographs of typical samples of $3 \mathrm{Al}_{2} \mathrm{O}_{3}: 3 \mathrm{SrCO}_{3}: \mathrm{SrSO}_{4}$ mixture, heat treated from 800 to $1150^{\circ} \mathrm{C}$ with $4 \mathrm{~h}$ isotherm. $\mathrm{A}: 800^{\circ} \mathrm{C}$, B: $900^{\circ} \mathrm{C}, \mathrm{C}: 1000^{\circ} \mathrm{C}, \mathrm{D}: 1100^{\circ} \mathrm{C}, \mathrm{E}$ and $\mathrm{F}: 1150^{\circ} \mathrm{C}$. 
the volume of the sample at constant speed, with the dimensioning the crystal grain boundary. Porosity is also present due to the generation of $\mathrm{CO}_{2}$ and grains geometric suffer contraction, as explained by the kinetic mechanism $R_{1.1}$. In Figure 3C the strontium oxide reacts with alumina present in the system to give rise to two aluminates was observed, the $\mathrm{SrAl}_{2} \mathrm{O}_{4}(4)$ and $\mathrm{Sr}_{3} \mathrm{Al}_{2} \mathrm{O}_{6}(5)$ according to EDS analysis. The latter with a spherical morphology and both are reacting strontium sulfate, $\mathrm{SrSO}_{4}(3)$. In Figure $3 \mathrm{D}$ nucleation of $\mathrm{Sr}_{4} \mathrm{Al}_{6} \mathrm{O}_{12} \mathrm{SO}_{4}(6)$ was observed within particles corresponding to $\mathrm{SrAl}_{2} \mathrm{O}_{4}(4)$, according to the analysis of EDS, as explained by the kinetic mechanism $P_{1.1}$. The growth of these nuclei are shown in Figure 3E where particles are identified corresponding to $\mathrm{Sr}_{4} \mathrm{Al}_{6} \mathrm{O}_{12} \mathrm{SO}_{4}$ (6), according to the analysis of EDS and as explained by the kinetic mechanism $P_{1.1}$. Figure $3 \mathrm{~F}$ is a magnification of a particle to observe the formation of agglomerates of microspheres for the $\mathrm{Sr}_{4} \mathrm{Al}_{6} \mathrm{O}_{12} \mathrm{SO}_{4}$ (6), according to the analysis of EDS. Figure 4 shows the curves of $\ln K$ versus $1 / T$ for both kinetic models. From this curves it was determined that the activation energy for the $R_{1.1}$ and $P_{1.1}$ models was $145.47 \mathrm{KJmol}^{-1}$ and $151.37 \mathrm{KJmol}^{-1}$, respectively.

\subsection{Crystal structure}

Structural refinement process was divided into three stages. Firstly, the size and shape of the unit cell was determined through the refining of diffraction patterns with the Rietveld method (using the Fullproof program). Second, as it is a compound with unknown crystal system, the unit cell parameters such as; Miller indices and numbers of atoms were determined analytically ${ }^{14}$. Finally, the positions of the atoms inside the unit cell were determined with the Rietveld method (using the Fullproof program). A prerequisite in order to begin with the structural determination of any compound is the verification of the purity of the sample. Figure 5 shows the $\mathrm{X}$-ray diffraction patterns for samples heat treated from 1200 to $1500^{\circ} \mathrm{C}$ with 4 hours isotherm (the right side shows a typical SEM micrograph of $\mathrm{Sr}_{4} \mathrm{Al}_{6} \mathrm{O}_{12} \mathrm{SO}_{4}$ compound).

The stability of the compound is observed up to $1500^{\circ} \mathrm{C}$ since only the peaks corresponding to the $\mathrm{Sr}_{4} \mathrm{Al}_{6} \mathrm{O}_{12} \mathrm{SO}_{4}$, are recorded without variation at intensities. Thus, the diffraction pattern employed for the structural determination was the heat treated at $1400^{\circ} \mathrm{C}$ with an isotherm of 4 hours. Recalling that the Fullprof program needs input crystallographic data to begin refining, crystal system, space group and atomic positions of the $\mathrm{Ca}_{4} \mathrm{Al}_{6} \mathrm{O}_{12} \mathrm{SO}_{4}$ were considered as initial variables ${ }^{15}$. Figure 6 shows the first and last stage of fitting of the X-ray diffraction patterns corresponding to $\mathrm{Sr}_{4} \mathrm{Al}_{6} \mathrm{O}_{12} \mathrm{SO}_{4}$ compound, where the evolutionary process of the method used is observed.

For the first refining (6A) a value of convergence 105 was obtained. This is reflected in the low fit between the experimental pattern (red spots) and the calculated pattern (solid black line), reflecting higher intensity peaks in the differential curve (solid blue line). In the last stage of refining (6B) the value of $\mathrm{Chi}^{2}$ was of 1.94 , reflecting this in the good fit between experimental and calculated pattern and low intensity peaks in the differential curve $\left(\mathrm{Y}_{\mathrm{obs}}-\mathrm{Y}_{\mathrm{cal}}\right)$. Considering the numbers of peak of the diffraction pattern as well as the crystal system that is refining (Orthorhombic), the results are acceptable. Figure 7 presents a scheme of the crystal structure of $\mathrm{Sr}_{4} \mathrm{Al}_{6} \mathrm{O}_{12} \mathrm{SO}_{4}$ strontium compound and crystallographic data.

Yellow spheres represent oxygen atoms (80), red spheres represent atoms of strontium (20), with spheres represent atoms of aluminum (30) and purple spheres represent atoms of sulfur (5). Tetrahedron are formed with sulfur and oxygen atoms. Atomic coordinates within the unit cell of the elements present in the compound are presented in Table 1.
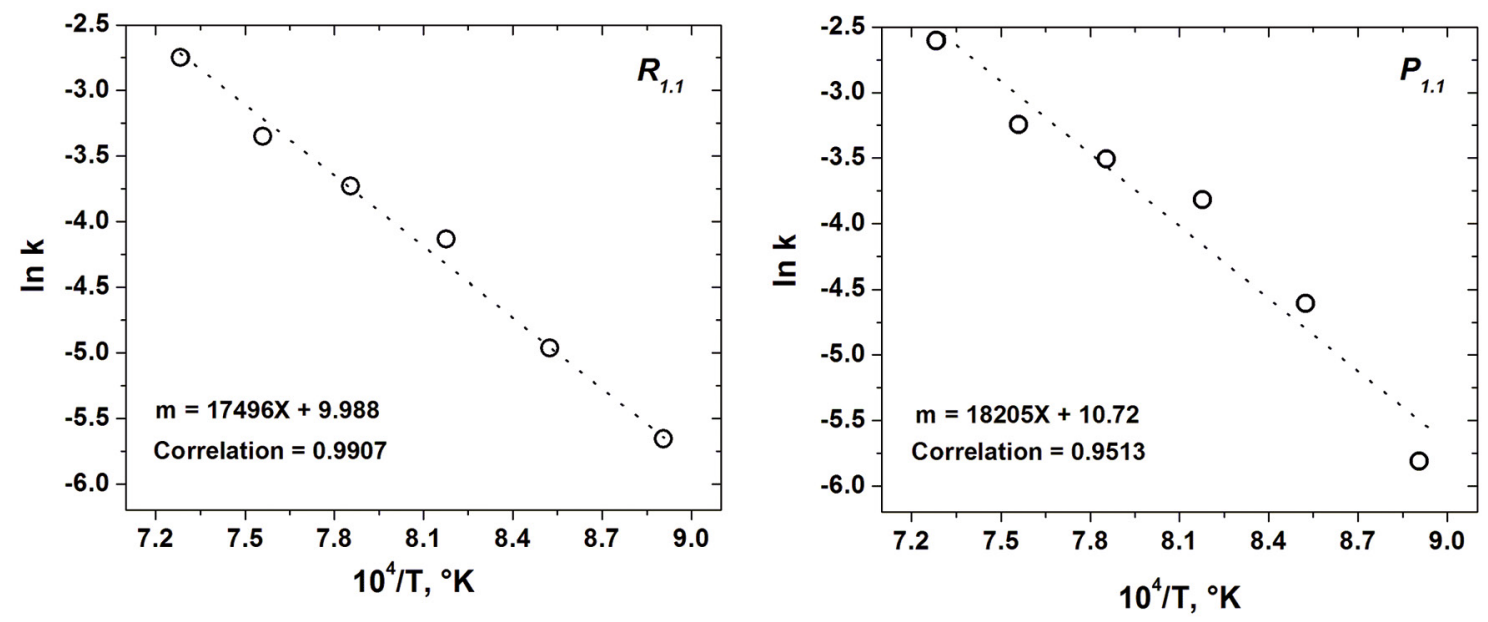

Figure 4: Activation energy curves for the two models involve in the formation of $\mathrm{Sr}_{4} \mathrm{Al}_{6} \mathrm{O}_{12} \mathrm{SO}_{4}$ strontium compound. 

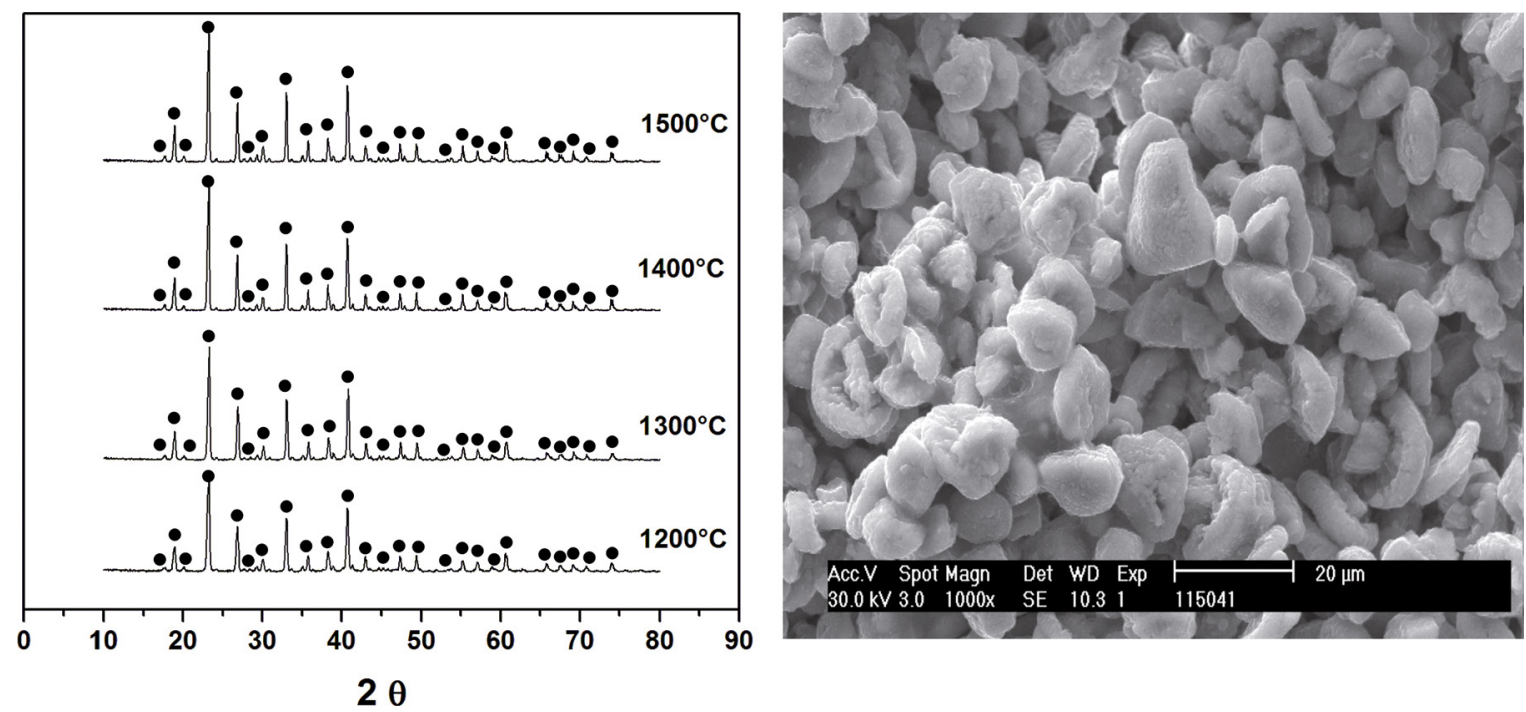

Figure 5. On the left patterns of X-ray diffraction of samples head treated at different temperatures with an isotherm of 4 hours. $\bullet$ : $\mathrm{Sr}_{4} \mathrm{Al}_{6} \mathrm{O}_{12} \mathrm{SO}_{4}$. On the right shows a typical SEM micrograph of $\mathrm{Sr}_{4} \mathrm{Al}_{6} \mathrm{O}_{12} \mathrm{SO}_{4}$ compound.
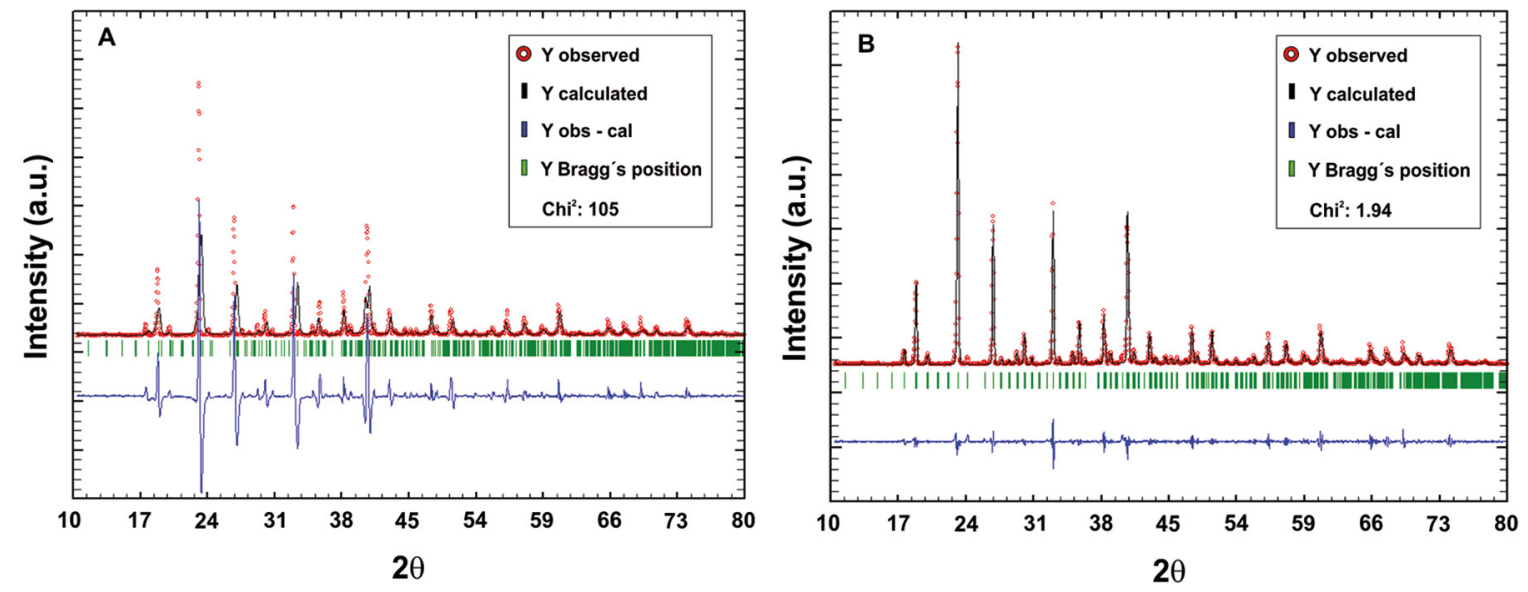

Figure 6: First (A) and last (B) stage of refining diffraction patterns, where the evolutionary process of the method used is observed.

\begin{tabular}{|l|l|}
\hline \multicolumn{2}{|c|}{$\mathbf{S r}_{4} \mathbf{A l}_{\mathbf{6}} \mathbf{O}_{\mathbf{1 2}} \mathbf{S O}_{\mathbf{4}}$} \\
\hline System & orthorhombic \\
\hline $\mathrm{a}$ & $13.32802 \AA$ \\
\hline $\mathrm{b}$ & $13.34430 \AA$ \\
\hline $\mathrm{c}$ & $9.38704 \AA$ \\
\hline $\mathrm{V}_{\text {cell }}$ & $1669.51414 \AA^{3}$ \\
\hline$\alpha=\beta=\gamma$ & $90^{\circ}$ \\
\hline Space group & $\mathrm{P} \mathrm{c} \mathrm{c} 2$ \\
\hline Chi $^{2}$ & 1.94 \\
\hline $\mathrm{R}_{\mathrm{B}}$ & 0.0985 \\
\hline $\mathrm{R}_{\text {wp }}$ & 0.137 \\
\hline $\mathrm{R}_{\mathrm{p}}$ & 0.0925 \\
\hline
\end{tabular}

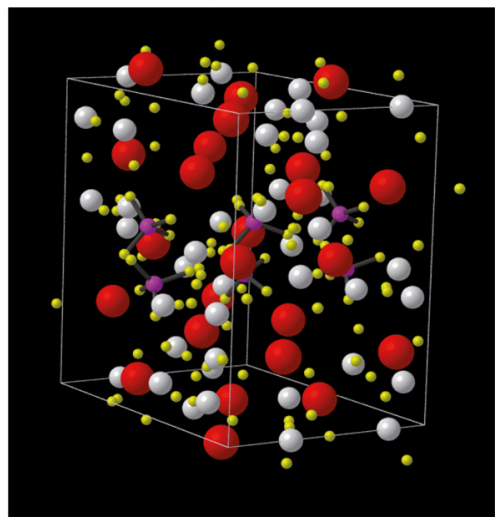

Figure 7: Representative scheme of the strontium compound (Sr4Al6O12SO4) crystal structure and crystallographic data. 
Table 1. Atomic coordinates of elements present in the $\mathrm{Sr}_{4} \mathrm{Al}_{6} \mathrm{O}_{12} \mathrm{SO}_{4}$ compound.

\begin{tabular}{|c|c|c|c|c|c|c|c|}
\hline Atom & Site & Symm & $\mathrm{x}$ & $\mathrm{y}$ & $\mathrm{z}$ & $\mathrm{B}_{\text {iso }}$ & $\mathrm{N}$ \\
\hline S & $4 e$ & 1 & 0.23248 & 0.26145 & 0.99946 & 1.94 & 1 \\
\hline $\mathrm{O}_{1}$ & $4 e$ & 1 & 0.69398 & 0.17179 & 0.46487 & 7.53 & 1 \\
\hline $\mathrm{O}_{2}$ & $4 e$ & 1 & 0.71946 & 0.28366 & 0.64036 & 7.53 & 1 \\
\hline $\mathrm{O}_{3}$ & $4 e$ & 1 & 0.75380 & 0.37383 & 0.35643 & 7.53 & 1 \\
\hline $\mathrm{O}_{4}$ & $4 e$ & 1 & 0.74686 & 0.34189 & 0.52310 & 7.53 & 1 \\
\hline $\mathrm{Sr}_{1}$ & $4 e$ & 1 & 0.04029 & 0.25116 & 0.20596 & 2.12 & 1 \\
\hline $\mathrm{Sr}^{2}$ & $4 e$ & 1 & 0.24918 & 0.94430 & 0.31484 & 2.12 & 1 \\
\hline $\mathrm{Sr}_{3}$ & $4 e$ & 1 & 0.25046 & 0.50859 & 0.25184 & 2.12 & 1 \\
\hline $\mathrm{Sr}_{4}$ & $4 e$ & 1 & 0.47142 & 0.25310 & 0.22199 & 2.12 & 1 \\
\hline $\mathrm{Al}_{1}$ & $2 d$ & 2 & 0.50000 & 0.50000 & 0.21402 & 0.43 & 0.5 \\
\hline $\mathrm{Al}_{2}$ & $2 c$ & 2 & 0.50000 & 0.00000 & 0.21886 & 0.43 & 0.5 \\
\hline $\mathrm{Al}_{3}$ & $2 a$ & 2 & 0.00000 & 0.00000 & 0.27619 & 0.43 & 0.5 \\
\hline $\mathrm{Al}_{4}$ & $2 b$ & 2 & 0.00000 & 0.50000 & 0.22988 & 0.43 & 0.5 \\
\hline $\mathrm{Al}_{5}$ & $4 e$ & 1 & 0.60945 & 0.11931 & -0.00144 & 0.22 & 1 \\
\hline $\mathrm{Al}_{6}$ & $4 e$ & 1 & 0.12955 & 0.63075 & 0.97962 & 0.22 & 1 \\
\hline $\mathrm{Al}_{7}$ & $4 e$ & 1 & 0.38466 & 0.63370 & 1.00064 & 0.22 & 1 \\
\hline $\mathrm{Al}_{8}$ & $4 e$ & 1 & 0.14003 & 0.87894 & 1.01419 & 0.22 & 1 \\
\hline $\mathrm{O}_{5}$ & $4 e$ & 1 & 0.40157 & 0.23684 & 0.48405 & 0.285 & 1 \\
\hline $\mathrm{O}_{6}$ & $4 e$ & 1 & 0.57030 & 0.40521 & 0.14814 & 1.385 & 1 \\
\hline $\mathrm{O}_{7}$ & $4 e$ & 1 & 0.55970 & 0.08789 & 0.15659 & 1.385 & 1 \\
\hline $\mathrm{O}_{8}$ & $4 e$ & 1 & 0.76434 & 0.59923 & 0.50746 & 1.385 & 1 \\
\hline $\mathrm{O}_{9}$ & $4 e$ & 1 & 0.57381 & 0.42887 & 0.86938 & 1.385 & 1 \\
\hline $\mathrm{O}_{10}$ & $4 e$ & 1 & 0.88455 & 0.42899 & 0.82469 & 1.385 & 1 \\
\hline $\mathrm{O}_{11}$ & $4 e$ & 1 & 0.75493 & 0.89768 & 0.55296 & 1.385 & 1 \\
\hline $\mathrm{O}_{12}$ & $4 e$ & 1 & 0.88215 & 0.04837 & 0.85993 & 1.385 & 1 \\
\hline $\mathrm{O}_{13}$ & $4 e$ & 1 & 0.58635 & 0.05465 & 0.87860 & 1.385 & 1 \\
\hline $\mathrm{O}_{14}$ & $4 e$ & 1 & 0.08647 & 0.24417 & 0.46583 & 1.385 & 1 \\
\hline $\mathrm{O}_{15}$ & $4 e$ & 1 & 0.93338 & 0.09127 & 0.16891 & 1.385 & 1 \\
\hline $\mathrm{O}_{16}$ & $4 e$ & 1 & 0.92837 & 0.41086 & 0.16104 & 1.385 & 1 \\
\hline
\end{tabular}

\section{Conclusions}

- The crystal structure of the $\mathrm{Sr}_{4} \mathrm{Al}_{6} \mathrm{O}_{12} \mathrm{SO}_{4}$ compound was determined using the Rietveld method. The shape of the unit cell is Orthorhombic, with next reticular parameters: $\mathrm{a}=13.32802 \AA, \mathrm{b}=13.34430 \AA$ and $\mathrm{c}=$ $9.38704 \AA$, the volume of cell is $1669.51414 \AA^{3}$ and has $\operatorname{Pcc} 2$ space group. The number of atoms within the unit cell was determined, existing 80 atoms of oxygen, 30 atoms of aluminum, 20 atoms of strontium and 5 atoms of sulphur. The atomic positions within unit cell were determined using the Fullproof, FOX and CARINE computational programs.

- The kinetics of formation of $\mathrm{Sr}_{4} \mathrm{Al}_{6} \mathrm{O}_{12} \mathrm{SO}_{4}$ is controlled by two models, $R_{l .1}$ (geometrical contraction at grain boundary, $1-(1-\alpha)^{1 / n}$ and $P_{1.1}$ (nucleation and growth by the energy law, $\left.\alpha^{1 / n}\right)$. The activation energies for these models were $145.47 \mathrm{KJmol}^{-1}$ and
$151.37 \mathrm{KJmol}^{-1}$, respectively. It was identified the formation of $\mathrm{Sr}_{3} \mathrm{Al}_{2} \mathrm{O}_{6}$ and $\mathrm{SrAl}_{2} \mathrm{O}_{4}$ as intermediate phases. The formation of $\mathrm{Sr}_{4} \mathrm{Al}_{6} \mathrm{O}_{12} \mathrm{SO}_{4}$ occurred at low temperature as $1150^{\circ} \mathrm{C}$.

\section{Acknowledgments}

Authors would like to thank to National Coucil of Science and Technology of México (CONACyT) for financial support for the development of this work as well as the processing laboratories and characterization of CINVESTAV-Saltillo and UPV for the technical support.

\section{References}

1. Quesada Gonzalez O, Torres GE, Llópiz JC. Termogravimetría de alta resolución: Estudio cinético de la deshidratación térmica 
del cloruro de bario dihidratado. Revista Cubana de Química. 2002;14(1):44-50.

2. Esteve Cano VJ, ed. El Método de Rietveld. $2^{\mathrm{a}}$ ed. Castellón: Universitat Jaume I; 2014.

3. Harris KD, Tremayne M, Kariuki BM. Contemporary Advances in the Use of Powder X-Ray Diffraction for Structure Determination. Angewandte Chemie (International ed. in English). 2001;40(9):1626-1651.

4. Tremayne M. The impact of powder diffraction on the structural characterization of organic crystalline materials. Philosophical Transactions. Series A, Mathematical, Physical, and Engineering Sciences. 2004;362(1825):2691-2707.

5. McCusker LB, von Dreele RB, Cox DE, Louër D, Scardi P. Rietveld refinement guidelines. Journal of Applied Crystallography. 1999;32:36-50.

6. Gilioli C, Massazza F, Pezzuoli M. A new compound: Strontium sulphoaluminate and its relationships with calcium sulphoaluminate. Cement and Concrete Research. 1971;1(6):621-629.

7. Brenchley ME, Weller MT. Synthesis and structure of sulfide aluminate sodalites. Journal of Materials Chemistry. 1992;2(10):1003-1005.

8. Rodríguez-García JA, Rocha-Rangel E, Torres-Torres J, Almanza-Robles JM. Synthesis by a solid state reaction of the $\mathrm{Sr}_{4} \mathrm{Al}_{6} \mathrm{O}_{12} \mathrm{SO}_{4}$ compound. Journal of Ceramic Processing Research. 2011;12(3):310-313.
9. Rodríguez-García JA, Rocha-Rangel E, Almanza-Robles JM, TorresTorres J, Leal Cruz AL, Munive GT. Chemical interaction of $\mathrm{Sr}_{4} \mathrm{Al}_{6} \mathrm{O}_{12} \mathrm{SO}_{4}$ with liquid aluminum alloys. In: Sing JP, Bansal NP, Goto T, Lamon J, Choi SR, Mahmoud MM, et al., eds. Processing and Properties of Advanced Ceramics and Composites IV: Ceramic Transactions, Volume 234. Hoboken: Willey; 2012. p. 21-27.

10. Rodríguez-García JA, Rocha-Rangel E, López Hernández J, Hernández-Bocanegra A, Leal-Cruz A, Almanza-Robles J, et al. Physical properties of the $\mathrm{Sr}_{4} \mathrm{Al}_{6} \mathrm{O}_{12} \mathrm{SO}_{4}$ ceramic compound. Wulfenia Journal. 2014;21(2):420-427.

11. Brown ME, ed. Handbook of Thermal Analysis and Calorimetry. Amsterdam: Elsevier Science B.V.; 1998. 691 p.

12. Chang YL, Hsiang HI, Liang MT. Phase Evolution During Formation of $\mathrm{SrAl}_{2} \mathrm{O}_{4}$ from $\mathrm{SrCO}_{3}$ and $\alpha-\mathrm{Al}_{2} \mathrm{O}_{3} / \mathrm{AlOOH}$. Journal of the American Ceramic Society. 2007;90(9):2759-2765.

13. Rojas-Hernandez RE, Rubio-Marcos F, Gonçalves RH, Rodriguez MA, Véron E, Allix M, et al. Original Synthetic Route To Obtain a $\mathrm{SrAl}_{2} \mathrm{O}_{4}$ Phosphor by the Molten Salt Method: Insights into the Reaction Mechanism and Enhancement of the Persistent Luminescence. Inorganic Chemistry. 2015;54(20):9896-9907.

14. Cullity BD. Elements of X-Ray Diffraction. $2^{\text {nd }}$ ed. Reading: Addison-Wesley; 1978.

15. Calos NJ, Kennard CHL, Whittaker AK, Davis RL. Structure of calcium aluminate sulfate $\mathrm{Ca}_{4} \mathrm{Al}_{6} \mathrm{O}_{12} \mathrm{~S}$. Journal of Solid State Chemistry. 1995;119(1):1-7. 